\title{
Dual-channel Supply Chain Integration Model Based on Double-helix Stability Structure of DNA Molecules
}

\author{
Hui Ye ${ }^{1,2, a}$, Mei-e Xie ${ }^{1,2, b}$ and Xiaolan $\mathrm{Hu}^{1,2, \mathrm{c}}$ \\ ${ }^{1}$ School of Business Administration, Wuhan Business University, Wuhan 430056 China; \\ 2 Development Research Center of Wuhan Modern Logistic, Wuhan, 430056 China. \\ a candye_h@foxmail.com, b253637228@qq.com, chelenhow001@163.com
}

\begin{abstract}
The purpose of supply chain integration is to improve the operating efficiency of supply chain, enhance the competitive advantage of each node enterprise, and constantly provide higher value for customers. Based on the basic theory of dual-channel supply chain operation, this paper constructs a dual-channel supply chain integration model by using the structural characteristics of DNA molecules and the relationship between core elements in the process of dual-channel integration. It aims to explore the process of channel value creation, weaken the conflict between channels, achieve synergistic effect, and provide the basis for the decision of channel integration.
\end{abstract}

Keywords: Dual-channel supply chain; Integration; DNA molecule.

\section{Introduction}

Horizontal integration is a kind of structure type of dual-channel supply chain, that is, traditional retailers operate independently, while manufacturers open up online electronic channels to increase market share. By combining the respective characteristics of online and offline channels, the resources of online and offline are integrated to maximize profits. The ultimate goal of the dualchannel supply chain integration is to achieve the synergistic effect, weaken the negative impact of channel conflict on the enterprises involved in the supply chain, and improve the common interests of the cooperative partnership.

Synergy is all the related activities carried out by various subsystems within the system to achieve the overall goal. Each subsystem and department cooperates with each other, and the cooperation and competition among them are interdependent[1]. Supply chain synergy is a process of value innovation, which can make up for the weak connection and limited value creation between internal and external activities and decision-making in supply chain. Collaborative integration of supply chain is to strengthen the close relationship between organizations, eliminate each other's resistance, take the premise of maximizing the overall benefit of the supply chain, take customers' demand as the orientation, and coordinate strategic objectives to ensure smooth flow of logistics, information flow and capital.

\section{Application of DNA Molecular Theory in Supply Chain}

DNA molecule is the carrier of genetic information of life, is the genetic unit of biology. DNA is composed of two nucleic acid chains that are entwined by base pairing in a double helix structure. Base pairing is fixed, and based on this pairing rule, DNA molecules have self-recognition and selfassembly functions. As long as one of the strands is used as a template, the other strand can be synthesized and duplicated according to the fixed base pairing sequence. The DNA molecules form a longitudinal layer stack by hydrogen bonding and double helix structure to ensure the stability of its structure. The ionic bonds formed between the phosphoric acid residues eliminates the repulsion between the DNA molecules and stabilizes the spatial structure.

According to the literature in recent years, it is found that there are not many articles that combine cytogenetics with supply chain to carry out research, but it provides certain theoretical support for the model construction of this paper. Noelm Tichy explores corporate DNA, that is, the enterprise is also a living body, with genetic factors of life [2]. Hui Zhou compares the capital chain and labor chain of enterprises to those of DNA molecules [3]. Many scholars have conducted comprehensive research 
on enterprise gene theory [4-5]. Tao Zhou proposed the supply chain gene, supply chain gene recombination and supply chain alliance, and constructed the supply chain model of gene recombination [6]. Based on the theory of DNA recombination, Jiani Tang etc. proposed the method of business process reengineering in supply chain, emphasizing the importance of relationship reorganization [7]. Through the summary of the literature, it is found that the application of DNA molecules to the supply chain has certain feasibility.

\section{Construction of a Collaborative Model of Dual-Channel Supply Chain Integration}

Based on the double-helical structure of DNA molecules, this paper constructed an online and offline dual-channel supply chain integration model as shown in the figure1. Combining with the characteristics of DNA molecular structure, this paper redefines the content of bases from the perspective of consumers and channel vendors. The base meanings are: A(actives) -degree of participation and experience effect; $\mathrm{T}$ (trust)- perceived risk and trust of products and enterprises; $\mathrm{G}$ (grabble) - information search; C (cost) - price and cost. Hydrogen bonds represent logistics, information flow, and capital flow. Deoxyribose represents quality products or services and phosphoric acid represents inventory levels.

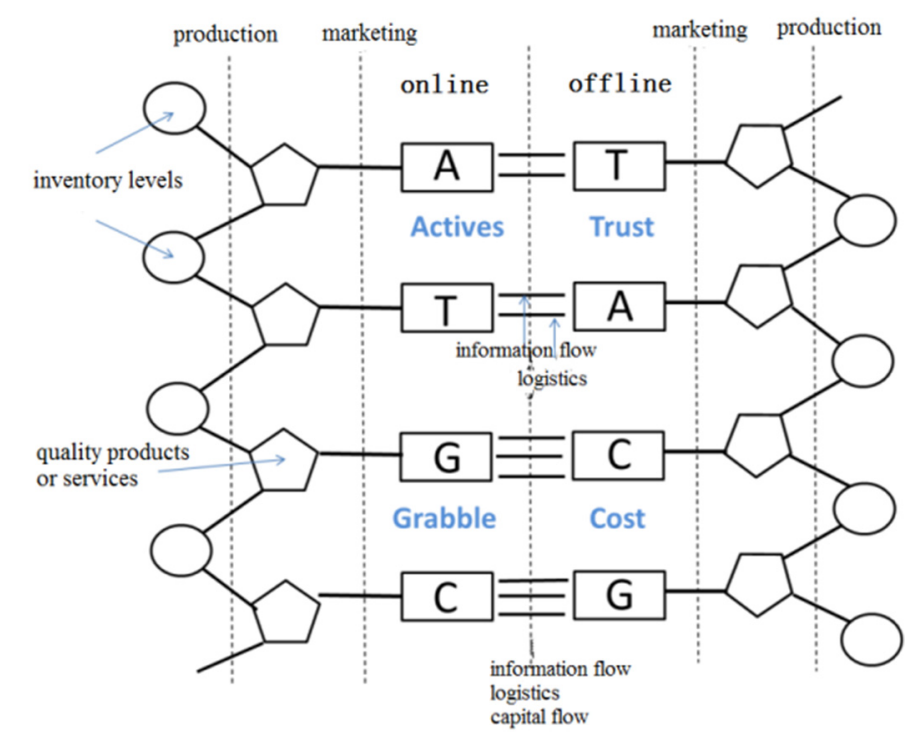

Fig. 1 Dual-channel supply chain integration model based on double-helix stability structure of DNA molecules

\subsection{A(actives)-T(trust)}

A (actives) - representing the degree of customers participation and the effect of the experience activity in a series of activities carried out by the enterprise for the consumer. It reflects the specific content of two integrated core elements of interactive customization and interactive experience effects. $\mathrm{T}$ (trust)- refers to consumers' subjective feelings about channel risks and trust in enterprises and products in the process of channel selection, which is closely related to enterprise brand image and popularity. The degree of customer's participation and the interaction effect in the value creation process of dual-channel supply chain affect the degree of customers' risk perception to the channels or products. One of the main factors in creating brand trust is the effect of the experience created by the manufacturer or the marketer.

The dual-channel supply chain in the mobile Internet environment allows customers to participate more in the value creation process. Especially in recent years, with the advancement of technology, many manufacturing industries have begun to attract customers to participate in product design and production in order to improve the market competitiveness. Customers participate in the value creation process through the Internet platform, which not only provides new design concept of 
product or service, but also creates conditions for customers and enterprises to have good communication, interaction and enjoyment experience.

Many scholars have conducted research on the relationship between experience and customers' loyalty[8-10]. Research has shown that there is a positive correlation between experience behavior and customers' loyalty, and negative consumption experience will have a smaller impact due to higher customers' loyalty. The impact of experience on customers' loyalty is not only obvious in the offline channel, but also in online channel. The customers' experience in shopping website is significantly positively related to brand emotion and brand trust, and indirectly affects website brand loyalty through brand trust.

Task interaction is one of the ways that companies take to interact with consumers. The purpose of task interaction is to cultivate users' repeated purchase behavior and increase the repeat purchase rate. Through the interaction of tasks, users' attention to products is enhanced, and a large number of loyal users are cultivated. Maintaining relationship interaction is a way to turn customers into "friends" and maintain existing customer relationships and gain trust.

\subsection{G(grabble)-C(cost)}

Information search is the main source of consumers' decision-making behavior, and it is the preparation work before implementing consumption behavior. By searching internal information, that is, past purchase experience and knowledge of its own reserves, it can help consumers to make decisions. When internal information cannot meet the judgment requirements, relevant data is obtained through external information search to support decision-making. The more experience of purchasing, the more knowledge of purchasing will be accumulated, the less perceived risk the customers will have, and the weaker the reliance on external search will be. Therefore, consumers rely more on internal search for channel selection decisions. Online channels are more used for information acquisition than online shopping. After obtaining certain information, it is possible to take consumption behavior offline. According to some research opinions, external search is more carried out in the process of shopping, because the search cost is greater than the search benefit, so the search of information will be reduced before purchase[11].

In the process of searching consumer information in offline channels, the search cost, potential benefits, contextual variables, purchase strategies, individual variables and other variables directly affect consumers' external search behavior[12]. Betterman sorted it out on this basis, and pointed out that the main factors influencing consumers' information search are individual differences, costbenefit comparison and conflict resolution strategy[13]. The context variable variable mainly refers to the effect of time pressure and economic pressure on the number of consumers' search. The higher the price of the product, the more consumers' information search behavior before purchase will increase. The frequency of external search is negatively correlated with consumers' knowledge storage of products[14], positively correlated with perceived risk[15] and product importance. Search effort refers to the effort and attention which consumers pay to collect information. The reason for active efforts is that consumers believe such search behavior can reduce their purchase costs and increase benefits[16].

Consumers' search costs vary depending on whether the product is homogeneous or not. The cost of searching under the homogeneous condition is composed of transportation cost, pain and discomfort caused by searching and leisure cost. Under the heterogeneous condition, the cost of information search is mainly composed of learning cost, the cost of understanding the credit status of the suppliers[17]. The price comparison search engine and free information resources on the Internet have reduced the cost of information search for consumers, and made it convenient for consumers to find the products they need quickly, thus reducing the cost of information search to some extent. However, in the Internet era, the amount of information is getting larger and larger, which makes it more and more difficult to obtain useful information and identify information and the transaction cost is getting higher and higher. The individual's income level represents the opportunity cost of time, so the cost of information search can be measured in terms of time cost[18]. 
Information search behavior directly affects consumers' consumption behavior and has a direct impact on the integration effect of the dual-channel supply chain. Lower search costs will enhance consumers' initiative and make their consumption behavior more rational. Through information technology, consumers make up for the information disadvantage, change from passive acceptance of products or services to active, and can fully understand and compare the product quality, brand image, reputation and price of products or enterprises, thus effectively reducing the risk in the purchase process.

\section{Summary}

The promotion of the Internet has driven the innovation of enterprises, the development of multidimensional profit space, and the promotion of diversified channels. The stability of multi-channel integration is reflected in maximizing the conflicts between channels and improving the synergy between channels. Integrating core elements is the key factor of decision-making in the operation of dual-channel supply chain. The dual-helix stability structure of DNA molecules provides a theoretical basis for the integration of the dual-channel supply chain. In the dual-channel integrated model, the degree of participation, the effect of interactive experience, the degree of perceived risk, and the trust of products and enterprises are paired as bases A and T, respectively. Harmonizing relationships between interaction activities and customer trust and perceived risk is the goal of strategic implementation. Based on the consumer's channel selection behavior theory and the relationship between information search and price and cost, information search and price and cost are used as bases $\mathrm{G}$ and $\mathrm{C}$ in the dual-channel supply chain integration model to provide the basis for channel integration decision-making.

\section{Acknowledgements}

Mei-e Xie is the corresponding author. This paper is supported by $\mathrm{PhD}$ project of Wuhan Business University (2017KB012).

\section{References}

[1]. Jeremy F, Shapiro. Modeling and IT Perspectives on Supply Chain Integration. Information Systems Frontiers. Vol. 3(2001) No.4, p.455-464.

[2]. Noelm T., Sherman S. Control Your Destiny or Someone Else Will. New York: Harper Business, 1993.

[3]. Hui ZHOU, Xinglv PENG. Research on Life Model of Enterprise. China Soft Science. (2000) No. 10, p.110-115.

[4]. Xiaoming XU, Jianhua DAI. The Evolution of Corporate Gene Theory and the Construction of Ciston Systematic New Model of Corporate Gene.Shanghai Manageement Science.(2008) No.2, p.86-90.

[5]. Jiao GAO. A preliminary study on the standard of enterprise DNA testing. Proceedings of the 9th China Youth Information and Management Scholars Conference. Hong Kong: GlobeLink.(2007) p.288-290.

[6]. Tao ZHOU. Research on Gene Recombination in Supply Chain. Research of Finance and Accounting. ( 2009) No.16, p.61-63.

[7]. Jiani TANG, Xiaotong LI. Analysis of Supply Chain Business Process Re-engineering Based on the DNA Recombination Model. Logistics Technology, Vol. 30 (2011) No. 4, p. 118-121.

[8]. Oliver R. L.. Whence Consumer Loyalty[J]. Journal of Marketing, (1999) No.63, p. 33-44. 
[9]. Flavian C., Guinaliu M., GurrcaR.. The Role Played by Perceived Usability, Satisfaction and Consumer Trust on Website Loyalty[J]. Information \& Management.Vol. 43 (2006) No. 1, p. 114.

[10]. Meyer T.. Experience-based Aspects of Shopping Attitudes: The Roles of Norms and Loyalty. Journal of Retailing and Consumer Services.(2008) No. 15, p. 324-333.

[11]. Beatty and Smith. External search effort an investigation across several product categories. The Journal of Consumer Research.Vol. 14(1987) No. 1, p. 83-95.

[12]. Newman, J.W. Consumer external search: amounts and determinants.Consumer and Industrial Buying Behavior.1977:79-94 Vol. 42 (2008) No. 11, p.

[13]. Betterman, J. R. An Information Processing Theory to Consumer Choice. Reading, MA: Addison Wesley. 1979.

[14]. Dongjing LI. Empirical research on the influencing factors and their results and satisfaction of consumers' efforts to search information. Management World. (2002) No. 11, p. 100-107.

[15]. Jing SUN, Zhi-Yu SHEN. Research on External Search and Innovation Performance from the Contingency Perspective: the Moderating Effect of Organizational Slack. South China Journal of Economics. (2014) No. 9, p. 1-13.

[16]. Sracevic T. Modeling interaction in information retrieval (IR): a review and proposal. In: Hardin, S., ed. 59th Annual Meeting of the American Society for Information Science. Silver Spring, MD: American Society for Information Science.1996: 3-9.

[17]. Yongjun LI. Search costs for consumption and Information screening. Market Modernization. Vol11 (2009) No. 4, p. 40-43.

[18]. Klein L R., Ford G T. Consumer Search for Information in the Digital Age: An Empirical Study of Pre-purchase Search for Automobiles[J]. Journal of Interactive Marketing.Vol. 17 (2003) No. 3, p. 29-49.

[19]. C. Marinagi, P. Trivellas, P. Reklitis.Information Quality and Supply Chain Performance: The Mediating Role of Information Sharing. Procedia - Social and Behavioral Sciences. (2015) No. 175 , p. $473-479$.

[20]. Jamie C., AronO'Cass, Dennis A.. Assessing customers' perceived value of the online channel of multichannel retailers: A two country examination. Journal of Retailing and Consumer Services. (2015) No.27, p. 90-102. 